\title{
Comparative Law and the Same-Sex Marriage Debate: A Step-by-Step Approach Toward State Recognition
}

\author{
William N. Eskridge, Jr."
}

On December 20,1999, the Vermont Supreme Court ruled in Baker v. Vermont ${ }^{1}$ that the state's different treatment of lesbian and gay couples under its marriage law violated the Vermont Constitution. ${ }^{2}$ In April 2000, the Vermont legislature responded by creating a new institution of "civil unions" for same-sex couples. In June 1999, the government of the Netherlands introduced legislation to recognize same-sex marriages. ${ }^{3}$ In one sense, a race has commenced: the Vermont plaintiffs and the Dutch government are each striving to make their jurisdiction the first in recent Western history to provide full, formal recognition to same-sex unions as legal marriages entailing the same rights and obligations as different-sex marriages.

In another sense, this may be a race without a winner. Pragmatists caution that Denmark moved to the brink of same-sex marriage in 1989 and the state of Hawaii seemed to be on the verge of recognizing same-sex marriage in 1993, yet both have hesitated in the face of popular criticism. Most fundamentally, moralists on both the right and left insist that this is a race that ought to have no winners. Both quail at the thought of legally recognized same-sex marriages or even civil unions: conservatives fear that gay marriage will constitute a state stamp of approval on homosexuality and sodomy, which should instead be considered flawed (at best) or evil (at worst) alternatives to preferred heterosexuality and procreative intercourse, while progressives fear that gay marriage will constitute a queer stamp of approval on the gendered and sex-negative features of middle-class family values.

I have discussed the conservative and progressive critiques of same-sex marriage in prior publications and have maintained that neither progressives nor conservatives have yet produced a convincing response to my argument that the principle of formal equality requires the state to recognize same-sex unions on the

* John A Garver Professor of Jurisprudence, Yale Law School. J.D., Yale Law School, 1978; M.A., Harvard University, 1974; B.A., Davidson College, 1973. This essay was originally presented at the University of Pacific, McGeorge School of Law in 1999 as part of McGeorge School of Law's Distinguished Speaker Series. I am grateful for the excellent research help provided by Joshua Stehlik.

1. 744 A.2d 864 (Vt. 1999).

2. Id. at 867.

3. See Kees Waaldijk, University of Leiden, The Latest About Lifting the Ban on Marriage for Same-Sex Couples in the Netherlands (visited Oct. 1999) <http://www.coc.n1/index.html?file=marriage> (copy on file with the McGeorge Law Review) (describing the Marriage Bill, which was formally introduced in the Netherlands' Parliament in June of 1999). 
same terms as which it recognizes different-sex unions. ${ }^{4}$ In this Essay, I not only demonstrate how the events in Vermont and Hawaii link up with those in the Netherlands and Denmark, but I also correlate those events with the broader constitutional and theoretical debates as well. My general thesis is that not only does comparative law reveal the current plurality of legal regulatory regimes, but it also suggests the likelihood of that pluralism's progressing, slowly but surely, to state recognition of same-sex unions, and to a pluralism of options for same-sex partners within most countries. My specific thesis is that comparative international and domestic experience suggests that, even if some conservative and progressive criticisms of same-sex marriage end up being true in the short term, most will not be borne out in the long term. Not only are the expressed fears of the religious right and radical queer theorists greatly overstated, but they are mutually offsetting as well.

\section{THE SAME-SEX MARRIAGE DEBATE}

In Loving v. Virginia, ${ }^{5}$ a unanimous United States Supreme Court invalidated Virginia's law prohibiting different-race marriages. Part I of Chief Justice Earl Warren's opinion ruled that denying a black-white couple a marriage license that would be given to a similar black-black couple is race discrimination in violation of the Equal Protection Clause of the United States Constitution. ${ }^{6}$ The Hawaii Supreme Court in Baehr v. Lewin ${ }^{7}$ applied this same kind of analysis to the State's bar to same-sex marriages. ${ }^{8}$ Specifically, the court in Baehr held that denying a female-female couple the marriage license that would be given to a similar femalemale couple is discrimination on the basis of sex, in the same way that denying a black-white couple a marriage license that would be given to a black-black couple is discrimination on the basis of race. 'In the latter case, the classification (the variable item) is the race of one partner; in the former case, the classification (the variable item) is the sex of one partner. Like the United States Constitution, the Hawaii Constitution makes sex a classification that cannot be used to confer legal disadvantages unless there is a compelling justification. ${ }^{10}$ That justification cannot be state encouragement of "natural" gender roles (husband and wife), because

4. The arguments are in William N. ESkridge, JR, THE CASE fOR SAME-SEX MARriage (1996) [hereinafter ESKRIDGE, THE CASE FOR SAME-SEX MARRIAGE], and WILLIAM N. ESKRIDGE, JR., GAYLAW: Challenging THE APARTHEID OF THE ClOSET chs. 6, 8 (1999) [hereinafter ESKRIDGE, GAYLAW].

5. 388 U.S. 1 (1967).

6. Id. at 7-12; U.S. CONST. amend. XIV, $\$ 1$.

7. 852 P.2d 44 (Haw. 1993).

8. Id. at 59-67.

9. Id. at 68 .

10. Haw. CONST. art. I, $\S 5$ ("No person shall be deprived of life, liberty, or property without due process of law, nor be denied equal protection of the laws, nor be denied the enjoyment of the person's civil rights or be discriminated against in the exercise thereof because of race, religion, sex or ancestry."). 
heightened scrutiny of sex-based classifications rests upon the idea that state insistence on rigid gender roles ordinarily limits individual choice without serving valid public goals.

Part II of Loving briefly presented an independent ground for striking down Virginia's law against different-race marriage:

The freedom to marry has long been recognized as one of the vital personal rights essential to the orderly pursuit of happiness by free men.... To deny this fundamental freedom on so unsupportable a basis as the racial classifications embodied in these statutes ... is surely to deprive all the State's citizens of liberty without due process of law. ${ }^{11}$

The United States Supreme Court in Zablocki v. Redhail ${ }^{12}$ applied this holding of Loving to invalidate a state bar to remarriage by people with outstanding child or spousal support obligations. ${ }^{13}$ Justice Thurgood Marshall's opinion for the Court ruled that no state restriction of the "'freedom of personal choice in matters of marriage and family life" can be sustained unless the state can show that its restriction is narrowly drawn to serve a compelling social purpose. ${ }^{14}$ Because there was no suspicious classification in Zablocki comparable to the race-based classification in Loving, the stricter judicial scrutiny applied in Zablocki was justified solely on its restriction of the right to marry. ${ }^{15}$

Zablocki involved an equal protection challenge and established a doctrinal structure logically applicable to other cases: a state law or practice that places a "direct legal obstacle in the path of persons desiring to get married" denies those persons the equal protection of the laws unless the state policy is "supported by sufficiently important state interests and is closely tailored to effectuate only those interests." $\mathrm{A}$ further implication of Zablocki is that the denial of state recognition of same-sex marriages on the same terms as different-sex marriages is a denial of formal equality that must be specially justified by the state. The legal consequences of state-recognized marriage in this country are vast-including duties of support and fidelity, presumptions of spousal authority and agency in the event of disability or death, rights against state or private interference in the spousal relationship, and more than a thousand duties and rights under federal law. There is serious debate

11. Loving, 388 U.S. at 12.

12. 434 U.S. 374 (1978).

13. Id. at 377 .

14. Id. at 385-87 (quoting Cleveland Bd. of Educ. v. LaFleur, 414 U.S. 632, 639-40 (1974)). Justice Lewis Powell concurred only in the Court's judgment, in large part because he believed the implications of the majority opinion would also support a right to same-sex marriage. Id. at 396-406 (Powell, J., concurring). Chief Justice Burger and Justice Stewart concurred only in the Court's result, while Justice Rehnquist dissented. Id. at 391 (Burger, C.J., and Stewart, J., concurring); id. at 407 (Rehnquist, J., dissenting).

15. Id. at 383-87.

16. Id. at 387 n.12, 388 . 
regarding whether the state over-rewards marriage or over-protects marital relations. However that debate is resolved, many legal consequences of marriage that are unequally apportioned in our society will remain. The principle of formal equality demands that couples wishing to assume these rights and duties ought to be allowed to do so, unless there is a neutral state justification for excluding them.

This principle of law is also a principle of common sense. Assume you are running a household of three children, and you set different groundrules as to important matters for different children, perhaps to the disadvantage of one particular child. ${ }^{17}$ Such a regime is a bad one: you are not only needlessly hurting the disfavored child, but you are likely spreading discord among the children and perhaps even spoiling the preferred children. A regime of unequal treatment invites jealousy and bad feelings. In this way, the principle of formal equality is a rule supported by practical experience as well as by the more abstract idea of the equal dignity and personhood of each human subject. This principle does not insist that everyone always be treated exactly the same-only that differences in treatment be justified neutrally and purposively.

The principle of formal equality means that the burden of persuasion as to same-sex marriage lies with the opponents. The issue should not be "Why gay marriage?" but should instead be "Why not gay marriage?"

At first, traditionalist opponents argued that different treatment is justified by the nature of marriage, which inevitably situates same-sex couples outside of it. For these critics, same-sex marriage is an oxymoron; such relationships, they argue descriptively, have never been recognized as marriages, ${ }^{18}$ and, they argue prescriptively, ought not be so recognized, because marriage ought to involve a man and a woman at least theoretically capable of having procreative sex. ${ }^{19}$ The descriptive argument is factually oversimple: societies in history, including many Native American tribes in this country, have recognized same-sex unions as marriages. ${ }^{20}$ It also begs the question: How should our society structure the legal institution of marriage? The prescriptive argument tries to answer that question, but is too dogmatic by demanding that procreation be an essential goal of marriage.

17. I am thinking of rules for which the different ages of the children do not make a difference. Thus, if Martha is taught how to drive at age fifteen and then gets her license at age sixteen, then thirteen-year-old Sally will expect the same treatment-not to be taught how to drive at age thirteen, but to be taught the way Martha was when she reaches age fifteen. Moreover, the rule of formal equality needs to be understood in light of context, which might be materially different for the two children. If Sally were blind, she should not be treated the same. Finally, formal equality can be sacrificed for a neutral reason, especially one related to the activity being regulated. If Sally proves herself to be a reckless driver during lessons at age fifteen, her parent(s) may justifiably postpone her applying for a license until she receives further instruction or proves herself more careful.

18. See, e.g., Baker v. Nelson, 191 N.W.2d 185, 186-87 (Minn. 1971) (holding that statute governing marriage does not authorize marriage between persons of the same sex, and such marriages are prohibited).

19. See, e.g., John M. Finnis, Law, Morality, and "Sexual Orientation," 69 NơRE DAME L. REV. 1049, 1063-76 (1994) (asserting that intercourse between spouses enables them to actualize the blessings of children and mutual affection).

20. See ESKRIDGE, THE CASE FOR SAME-SEX MARRIAGE, supra note 4, ch. 2. 
Should infertile couples, including elderly couples, be disabled from marrying? No state has ever imposed such a requirement, and none could under the Supreme Court's right-to-marry jurisprudence. As the Court officially recognized in its last right-to-marry case, Turner $v$. Safley, ${ }^{21}$ the first and, for most people, the most important role of marriage is "expression[] of emotional support and public commitment"-namely, the unitive goal of marriage (as opposed to its procreative goal). ${ }^{22}$

Moreover, this kind of oppositionist rhetoric buttresses the sex discrimination argument for same-sex marriage by showing how resistance to same-sex marriage rests upon an insistence on rigid gender roles. To tell a woman that she cannot legally marry a woman is to restrict the woman's choice more fundamentally than to tell her she cannot attend the Virginia Military Institute (VMI) or administer her parents' estate..$^{23}$ To tell a woman that the state will recognize her committed union only if she agrees to be a wife to a wedded husband is a more dogmatic insistence on rigid gender roles than is a state's decision to allow eighteen-year-old women, but not eighteen-year-old men, to buy $3.2 \%$ beer. ${ }^{24}$ If women's exclusion from VMI and state preference in beer sales are both unconstitutional, as the Supreme Court has held, ${ }^{25}$ because they limit choice and rest upon rigid gender roles, then refusing to recognize a woman's choice of another woman as her life partner is not only just as unconstitutional, but more deeply so.

Although the definitional argument against same-sex marriage prevailed among judges and legislators before the 1990s, this argument's factual ignorance and normative sexism reinforces the power of my argument of formal equality. The factual ignorance of the definitional argument suggests that other motives were at work. The usual suspect is homophobia, which is inspired not just by the disgust that oral or anal sex arouses in many Americans, but is more fundamentally inspired by women's and men's abandonment of traditional gender roles. ${ }^{26}$ The rigid gender roles insisted upon by the definitional argument suggest that ultimately it is sexism

21. 482 U.S. 78 (1987) (protecting incarcerated prisoners' right to marry).

22. Id. at 95 . Turner did not change the analytical structure created by Loving and Zablocki, which requires the state to justify with the strongest policy reasons why it excludes some couples from the marriage rights routinely granted to others. What Tumer did clarify was the nature of the right itself. Loving and Zablocki gave some emphasis to the procreative goal of marriage. Tumer, in contrast, stressed the social, or unitive, goal of marriage, where marriage is an institution of commitment. Because some of the prisoners would never be able to consummate their marriages, the unitive goal was the only one applicable for many in the protected class.

23. See Virginia v. United States, 518 U.S. 515 (1996) (public paramilitary college cannot exclude women); Reed v. Reed, 404 U.S. 71 (1971) (state cannot give males a preference in administering estates even if, as implied, men are likely to have more business experience).

24. Cf. Craig v. Boren, 429 U.S. 190, 199-210 (1976) (holding it unconstitutional sex discrimination for the state to allow eighteen-year-old women, but not eighteen-year-old men, to buy $3.2 \%$ beer, even though there was strong evidence that men were more likely to drink and drive than were women).

25. See Virginia, 518 U.S. at 519; Craig, 429 U.S. at 199-210.

26. Although adulterous President William Clinton survived the knowledge that he was regularly fellated by White House intern Monica Lewinski, you can be sure the reaction would have been more severe if the President had been fellated by the equally obsequious George Stephanopolous. 
that drives this exclusion, thereby mobilizing the moral and political force of sex discrimination jurisprudence. Same-sex couples, and couples that resist easy classification as same- or different-sex, ought to be treated the same as conventional different-sex couples in the eyes of the law.

While the definitional argument against same-sex marriage remains popular, it has been supplemented and, among intellectuals, replaced by other arguments that are explicitly consequentialist. Such arguments focus on assertedly bad social consequences that follow from legal recognition of same-sex marriages. Some conservatives maintain that same-sex marriage would promote homosexuality and place a state "stamp of approval" on a status that is either wicked or suboptimal, especially for impressionable adolescents who would otherwise marry, procreate, and raise a family. ${ }^{27}$ Some progressives maintain that same-sex marriage would promote patriarchal marriage and place a state stamp of approval on assimilation of gay people into the straight mainstream, ${ }^{28}$ an assimilation that they view as wicked or suboptimal, especially for impressionable adolescents who might otherwise blaze their own queer paths. ${ }^{29}$

Both critiques of same-sex marriage make unsupported factual assumptions and wantonly speculate about the consequences of same-sex marriage. Also, both critiques cannot be right: many radical progressives would be delighted if same-sex marriage actually did promote homosexuality, and at least some conservatives ought to be satisfied if it gave marriage a helping hand. Relatedly, the newer conservative and progressive critiques help answer one another: conservatives should heed the progressive observation that same-sex marriage is state encouragement of interpersonal commitment most of all, while progressives ought to concede the conservatives' observation that same-sex marriage would contribute to the erosion of traditional gender roles (patriarchy) within the institution of marriage, which promises to open up more choices for women as well as men. Especially as attenuated, neither criticism can trump the principle of formal equality, and critics of both stripes would better focus their time and energy on issues that actually advance the values they advocate; conservatives might spend more energy supporting marriages of all kinds and remedying the tendency of men to dump and pauperize their wives who tend to invest more in the relationship, the children, and even the husbands' careers, while progressives might work toward social and institutional supports for more informal families of choice, such as friendship linkages and community support groups.

27. E.g., RICHARD A. POSNER, SEX AND REASON 311 (1992).

28. See Nancy D. Polikoff, We Will Get What We Ask For: Why Legalizing Gay and Lesbian Marriage Will Not "Dismantle the Legal Structure of Gender in Every Marriage," 79 VA. L. REv. 1535, 1536-43 (1993).

29. E.g., Paula L. Ettelbrick, Since When Is Marriage a Path to Liberation?, NAT'L GAY \& LESBIAN Q., Fall 1989, at 9, 9-12, reprinted in WILLIAM N. ESKRIDGE, JR. \& NAND. HUNTER, SEXUALITY, GENDER, AND THE LAW (1997). 
One source of insight that is largely absent from the same-sex marriage debate has been comparative law. Six countries-Denmark, Sweden, Norway, Iceland, Greenland, and the Netherlands-have adopted laws endowing registered same-sex partnerships with almost all the legal rights and duties associated with marriage. ${ }^{30}$ France has created a new institution, the civil solidarity pact, which includes some of the benefits and duties related to marriage of same-sex couples. Canada and Hungary have allowed same-sex partners all the benefits and obligations legally accorded different-sex cohabiting couples. What lessons does the comparative experience offer the same-sex marriage debate? Surprisingly many.

\section{SAME-SEX PARTNERSHIPS IN OTHER COUNTRIES}

The tables below set forth basic comparative law information for state regulation of gay people and their unions, including same-sex registered partnerships. These tables tell us nothing about the subjective experience of samesex couples in any of these countries, and it is too early to tell how state recognition of same-sex partnerships will play out. Nonetheless, these tables do tell us much about the path to legalized same-sex marriage. The path is step-by-step and incremental, inevitable in some jurisdictions, impossible elsewhere in the short term, and sedimentary in the sense that new institutions are being piled on top of old ones. Consider these points in some detail.

\section{A. The Step-by-Step Principle}

Table 1 sets forth, for selected countries, the dates on which each country adopted a progay change in its law: repealing laws criminalizing consensual sodomy, equalizing the age of consent for same-sex and different-sex intercourse, prohibiting discrimination on the basis of sexual orientation, affording same-sex cohabiting couples the same rights and obligations as different-sex couples, recognizing same-sex unions as "registered partnerships" or the like, and expressly allowing same-sex partners to adopt children on the same terms as married couples. Only Denmark has adopted all these gay-equality measures. Most countries in the table-and a large majority not in the table-have adopted few or none.

The overriding lesson of Table 1 is that legal recognition of same-sex unions-or, ultimately, marriages-comes through a step-by-step process. ${ }^{31}$ Such a process is sequential and incremental: it proceeds by little steps that are taken in

30. References for the laws discussed in this paragraph can be found in Appendix I to this Article.

31. The materials contained in Table 1 are taken from Appendix I, supra. See generally THE SOCIOLEGAL CONTROL OF HOMOSEXUALITY: A MULTI-NATION COMPARISON (Donald J. West et al. eds., 1997) [hereinafter MULTI-NATIONAL COMPARISON]; International Lesbian and Gay Association, World Legal Survey (visited Apr. 2000) <http://www.ilga.org> (copy on file with the McGeorge Law Review). 
a particular order..$^{32}$ Registered partnership laws, just short of same-sex marriage, have not been adopted until a particular country has first decriminalized consensual sodomy and equalized the age of consent for homosexual and heterosexual intercourse, then has adopted laws prohibiting employment and other kinds of discrimination against gay people, and finally has provided other kinds of more limited state recognition for same-sex relationships, such as the giving of legal benefits to or the enforcing of legal obligations on cohabiting same-sex couples.

The recurrence of the same pattern in country after country suggests this paradox: law cannot move unless public opinion moves, but public attitudes can be influenced by changes in the law. For gay rights, the impasse suggested by this paradox can be ameliorated or broken if the proponents of reform move step-bystep along a continuum of little reforms. There are a number of pragmatic reasons why such a step-by-step process can break the impasse over a period of time. Stepby-step change permits gradual adjustment of anti-gay mindsets, slowly empowers gay rights advocates, and can discredit anti-gay arguments. Consider each.

32. See Kees Waaldijk, The "Law of Small Change": How the Road to Same-Sex Marriage Got Paved in the Netherlands 1-3 (July 1999) (unpublished manuscript, on file with the author). This paper was authored for and presented at a conference entitled Legal Recognition of Same-Sex Partnerships: A Conference on National, European, and International Law, in London, England. 
Table 1

Progay Laws Outside the USA, Selected Countries

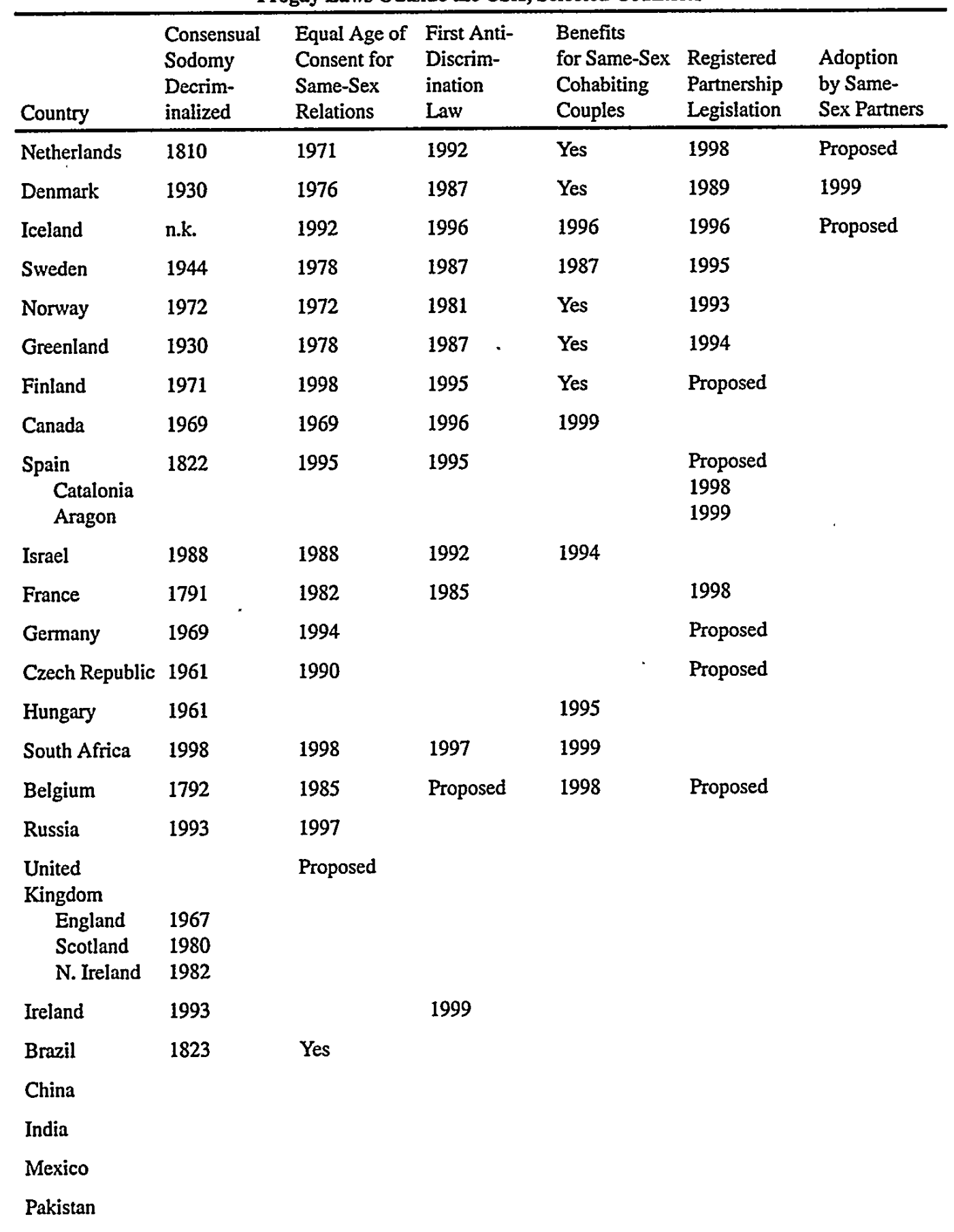


Paul's experience on the road to Damascus is exceptional; human beings rarely change their fundamental attitudes overnight. But one's anti-gay attitudes-or at least one's willingness to give vent to or act on them-can change as the culture changes. If you are a thirty-year-old man who is sickened by the idea of homosexuality or of "homosexuals," you are highly unlikely to support gay marriage, but you might be open to sodomy decriminalization for practical reasons, such as your belief that the state is wasting its time snooping around people's bedrooms. Yet sodomy decriminalization and a lessening of public condemnation of homosexuality will sooner or (probably) later embolden some of your gay friends, family members, and coworkers to come out of their closets. You will probably be shocked at first, and you can assimilate them as exceptions to your dislike of "homosexuals," but there is a good chance that some of your anti-gay attitudes will soften as you enter middle age. ${ }^{33}$ Over time, maybe a long period of time, your interaction with gay people might open you up to acquiescing in antidiscrimination laws, for your experience has been that gay coworkers are okay and that anti-gay workers are troublemakers. You could still oppose same-sex marriage, but even this attitude might bend when your daughter partners with another woman and you and your spouse integrate her into your extended family in a variety of ways. Because your other children have long known of your daughter's orientation, they are cool with the issue more generally. As each step in the progression toward gay equality encourages more people to be openly gay, not only can middle-aged homophobic attitudes change, but the attitudes of new generations might start out less homophobic. These changes will support gay equality. The foregoing is, however, only one among several possible scenarios. Because the homophobe may have a traumatic experience that confirms his dislike or simply ignores or denies positive information, his preexisting anti-gay attitudes may be completely resistant to change. ${ }^{34}$

Even if underlying attitudes do not change significantly, legal incrementalism can contribute to gay equality. In this regard, consider not only the information in Table 1, but that in Table 2, on the next two pages. ${ }^{35}$ Table 2 sets forth, for all 50 American states and the District of Columbia, the dates on which each state adopted a progay change in its law: repealing laws criminalizing consensual sodomy (or

33. Surveys have found that knowing gay people is negatively correlated with having anti-gay attitudes. See Gregory M. Herek, Beyond "Homophobia": A Social Psychological Perspective on Attitudes Toward Lesbians and Gay Men, in BASHERS, BAITERS \& BIGOTS: HOMOPHOBIA IN AMERICAN SOCIETY 1, 13-15 (John P. DeCecco ed., 1985).

34. On the strong persistence of anti-gay attitudes notwithstanding gay liberation and thousands of coming out stories, see ALBERT D. KLASSEN ET AL., SEX ANDMORALITY INTHEU.S.: ANEMPIRICAL ENQUIRY UNDER THE AUSPICES OF THE KINSEY INSTTTUTE 165-84 (Hubert J. O'Gorman ed., 1989).

35. The information found in columns one, three, and four of Table 2 are taken from ESKRIDGE, GAYLAW, supra note 4, at 328-37, 356-61; the data contained in columns three, four, and five is from WiLLIAM N. ESKRIDGE, JR. \& NAN D. HUNTER, SEXUALITY, GENDER, AND THE LAW 863-68, 949 (1997); the materials found in columns two and six are taken from Appendices II and III, supra. 
reducing it to a misdemeanor), enhancing defendants' sentences for crimes involving gay-bashing, prohibiting sexual orientation discrimination in public and (then) private employment, allowing a same-sex partner to adopt her partner's children as a "second parent," and extending benefits to state employees who are same-sex "registered partners."

Table 1 and 2 suggest that discriminalization of sodomy might pave the way-and probably is a precondition-for the adoption of anti-discrimination laws. Not only does sodomy repeal remove a popular objection to anti-discrimination laws, ${ }^{36}$ but it facilitates the political conditions for such laws. Repeal of sodomy laws not only emboldens some gay people to come out of their closets, but also emboldens the uncloseted to organize themselves politically and press for other equality assurances, such as laws that prohibit discrimination against them in the private as well as public spheres. ${ }^{37}$ The more openly gay people there are and the better organized they are politically, the greater attention politicians and judges will pay to their arguments for equal legal entitlements, even if popular attitudes are otherwise unaffected. Again, the dynamics might work the opposite way under unfavorable circumstances: if the newly uncloseted were to cause some terrible incident, there could be a backlash not only against further rights for gay people, but also against the new rights that had just been recognized.

36. That is, one can logically object to adopting an anti-discrimination law that protects people whose conduct (such as consensual sodomy) is habitually criminal. How can you protect a status group whose characteristic conduct is felonious? For an argument of this sort, see Romer v. Evans, 517 U.S. 620, 640-43 (1996) (Scalia, J., dissenting).

37. Because members of a potential interest group have incentives to "free ride" on the efforts of others, diminished political activity will ordinarily occur on behalf of that group. For gay people, the free rider problem is particularly severe, because most gay people are closeted. Once uncloseted, gay people's incentives to organize are much greater, but are impeded by threats of losing their jobs or other private as well as public retaliation. 
Table 2

Progay Legal Measures, States of the USA

\begin{tabular}{|c|c|c|c|c|c|c|}
\hline State & $\begin{array}{l}\text { Sodomy } \\
\text { Decrim. }\end{array}$ & $\begin{array}{l}\text { Hate } \\
\text { Crime }\end{array}$ & $\begin{array}{l}\text { Public } \\
\text { Emp. } \\
\text { Discrim. }\end{array}$ & $\begin{array}{l}\text { Private } \\
\text { Emp. } \\
\text { Discrim. }\end{array}$ & $\begin{array}{l}\text { Second } \\
\text { Parent } \\
\text { Adoptions }\end{array}$ & $\begin{array}{l}\text { Registered } \\
\text { Partner- } \\
\text { ship }\end{array}$ \\
\hline Vermont & 1977 & 1989 & 1991 & 1991 & 1993 & 1998 \\
\hline California & 1975 & 1991 & 1979 & 1979 & $(1980 s)$ & 1999 \\
\hline Hawaii & 1972 & & 1991 & 1991 & & 1995 \\
\hline D.C. & 1994 & 1990 & 1977 & 1977 & 1995 & 1994 \\
\hline New Jersey & 1978 & 1995 & 1991 & 1991 & 1995 & \\
\hline Massachusetts & (1974) & 1996 & 1989 & 1989 & 1993 & \\
\hline New York & 1980 & & 1983 & . & 1995 & \\
\hline Illinois & 1961 & 1991 & 1996 & & 1995 & \\
\hline Minnesota & (1977) & 1989 & 1986 & 1993 & & \\
\hline Wisconsin & 1983 & 1991 & 1982 & 1982 & & \\
\hline Connecticut & 1969 & 1990 & 1991 & 1991 & & \\
\hline New Hampshire & 1973 & 1997 & 1997 & 1997 & & \\
\hline Nevada & 1993 & 1989 & 1999 & 1999 & & \\
\hline Rhode Island & 1998 & 1991 & 1985 & 1995 & & \\
\hline Oregon & 1971 & 1989 & 1987 & & & \\
\hline Washington & 1975 & 1993 & 1985 & & & \\
\hline Pennsylvania & 1980 & & 1975 & & & \\
\hline Ohio & 1972 & & 1983 & & & \\
\hline Colorado & 1971 & & & & & \\
\hline Louisiana & 1999 & 1997 & & & & \\
\hline Delaware & 1972 & 1997 & & & & \\
\hline Iowa & 1976 & 1992 & & & & \\
\hline Kentucky & 1992 & 1998 & & & & \\
\hline Maine & 1975 & 1995 & & & & \\
\hline Nebraska & 1977 & 1997 & & & & \\
\hline Florida & (1971) & 1991 & & & & \\
\hline Alaska & 1978 & & & & & \\
\hline Georgia & 1998 & & & & & \\
\hline Indiana & 1976 & & & & & \\
\hline Montana & 1997 & & & & & \\
\hline New Mexico & 1975 & & & & & \\
\hline North Dakota & 1973 & & & & & \\
\hline South Dakota & 1976 & & & & & \\
\hline Tennessee & 1996 & & & & & \\
\hline
\end{tabular}

652 
Table 2

Progay Legal Measures, States of the USA

\begin{tabular}{lllllll}
\hline State & $\begin{array}{l}\text { Sodomy } \\
\text { Decrim. }\end{array}$ & $\begin{array}{l}\text { Hate } \\
\text { Crime }\end{array}$ & $\begin{array}{l}\text { Public } \\
\text { Emp. } \\
\text { Discrim. }\end{array}$ & $\begin{array}{l}\text { Private } \\
\text { Emp. } \\
\text { Discrim. }\end{array}$ & $\begin{array}{l}\text { Second } \\
\text { Parent } \\
\text { Adoptions }\end{array}$ & $\begin{array}{l}\text { Registered } \\
\text { Partner- } \\
\text { ship }\end{array}$ \\
\hline $\begin{array}{l}\text { West Virginia } \\
\text { Wyoming }\end{array}$ & 1976 & & & & \\
Maryland & 1977 & & & & \\
Arizona & $(1977)$ & $(1997)$ & & & \\
Arkansas & $(1977)$ & & & & \\
Kansas & $(1969)$ & & & \\
Michigan & $(1980)$ & & & & \\
Missouri & $(1977)$ & & & & \\
Texas & $(1973)$ & & & \\
Alabama & & & & \\
Idaho & & & & \\
Mississippi & & & & \\
North Carolina & & & & \\
Oklahoma & & & \\
South Carolina & & & & \\
Virginia & & & \\
Utah & & & & \\
\end{tabular}

Another way that incrementalism works to facilitate gay equality is even more subtle but is potentially powerful in the long term. Opponents typically argue that pro-gay measures will have catastrophic consequences-rampant promiscuity and public lewdness, predation against children, and erosion of families. ${ }^{38}$ These ills do not in fact occur when states adopt gay equality measures, in part because the predictions are irrational and hysterical to start with, and in part because the measures are so incremental. When sodomy laws are repealed, gay people do not drastically change their sexual practices, and only a minority of gay people are encouraged to be bolder in the public arena. The Scandinavian registered partnership laws dramatically illustrate how the persistence of the closet can itself contribute to arguments for gay rights. As Table 3 reveals, ${ }^{39}$ few same-sex couples have registered under Scandinavian partnership laws offering them almost all the benefits and obligations pertaining to different-sex married couples. Not only have

38. E.g., GEORGE GRANT \& MARK A. HORNE, LEgISLATING IMMORALITY: THE HOMOSEXUAL RightS MOVEMENT COMES OUT OF THE CLOSET (1993). See also ESKRIDGE, GAYLAW, supra note 4, ch. 3, for examples of exaggerated predictions made by opponents of gay rights in the 1970 s.

39. Table 3 is taken from materials distributed at the Conference on Legal Recognition of Same-Sex Partnerships organized by Professor Robert Winterute (Kings College) for July 1999. 
few couples registered under these laws, but observation by scholars in those countries has detected no significant effects, good or bad, for the society as a whole. The incrementalism-indeed, the sloth-like pace-by which social practices and law have changed undermines the apocalyptic rhetoric of anti-gay groups. The homophobes who cried wolf against sodomy repeal lose some credibility when they cry wolf again during debates about anti-discrimination laws and measures recognizing same-sex unions.

Table 3

Partnership Registration in Five Countries, $1990-98$

\begin{tabular}{cccccc}
\hline & Denmark & Norway & Sweden & Iceland & Netherlands \\
\hline 1990 & 746 & n.s. & n.s. & n.s. & n.s. \\
$(\mathrm{MMM} / \mathrm{FF})$ & $(573 / 173)$ & & & & \\
1991 & 258 & n.s. & n.s. & n.s. & n.s. \\
$(\mathrm{MM} / \mathrm{FF})$ & $(171 / 87)$ & & & & \\
1992 & 218 & n.s. & n.s. & n.s. & n.s. \\
$(\mathrm{MM} / \mathrm{FF})$ & $(139 / 79)$ & & & & \\
1993 & 185 & n.s. & n.s. & n.s. & n.s. \\
$(\mathrm{MMM} / \mathrm{FF})$ & $(124 / 61)$ & & & & \\
1994 & 197 & 294 & n.s. & n.s. & n.s. \\
$(\mathrm{MM} / \mathrm{FF})$ & $(105 / 92)$ & $(203 / 91)$ & & & \\
1995 & 194 & 98 & 333 & n.s. & n.s. \\
$(\mathrm{MM} / \mathrm{FF})$ & $(119 / 75)$ & $(64 / 34)$ & $(249 / 84)$ & & \\
1996 & 199 & 127 & 160 & n.s. & n.s. \\
$(\mathrm{MMM} / \mathrm{FF})$ & $(106 / 93)$ & $(80 / 47)$ & $(101 / 59)$ & & \\
1997 & 178 & 118 & 131 & 33 & n.s. \\
$(\mathrm{MM} / \mathrm{FF})$ & $(101 / 77)$ & $(75 / 43)$ & $(79 / 52)$ & $(16 / 17)$ & \\
1998 & 197 & n.a. & 125 & 12 & 5217 \\
$(\mathrm{MMM} / \mathrm{FF})$ & $(84 / 113)$ & & $(79 / 46)$ & $(5 / 7)$ & $(1860 / 1487)$ \\
Total & 2372 & 674 & 749 & 45 & 5217 \\
$(\mathrm{MM} / \mathrm{FF})$ & $(1498 / 874)$ & $(442 / 232)$ & $(508 / 241)$ & $(21 / 24)$ & $(1860 / 1487)$ \\
& & & & &
\end{tabular}

\section{B. The Progressivity Thesis}

The foregoing incremental and sequential process is also progressive: each step in this process is a step toward formal equality for lesbians, gay men, bisexuals, and possibly transgendered people. While recognition of same-sex unions is impossible and barely conceivable until other anti-discrimination measures have been adopted, and anti-discrimination laws are usually not possible until sodomy has been decriminalized, the decriminalization of sodomy makes it easier to adopt antidiscrimination laws, which in turn make it easier to recognize same-sex unions, for the reasons developed above. Once same-sex unions are euphemistically recognized as "registered partnerships," and modest numbers of people take advantage of the new institution to formalize their well-ordered middle-class unions, it would then be, I hypothesize, a smaller step to recognize same-sex marriage. The implication is that recognition of same-sex marriage is likely, so long as: (1) the preparatory 
steps are followed; (2) gay people come out of their closets and insist on equal rights; and (3) society does not perceive disastrous consequences flowing from the steps it has already taken.

This is a breathtaking thesis only if viewed in the short term. Fifty years ago, it would have been preposterous to think that consensual sodomy would be widely decriminalized in the United States, as it is today (Table 2). Thirty years ago, extending antidiscrimination protections to gay people in the workplace would have been unthinkable almost anywhere in the Western world, whereas today such protections are commonplace (Tables 1 and 2). Fifteen years ago, it would have been visionary to think that a Western state would create a registry and benefits for same-sex partnerships, such as now exist in seven countries (Tables 1 and 3 ) and the state of Vermont, and insane to believe that same-sex marriages would be seriously debated all over Europe and the United States, as they are today. Yet the beginning of the millennium bears witness to the seriousness of this debate. The Netherlands or Vermont may or may not recognize same-sex marriages in the next few years, but some state will in the foreseeable future. Once that happens, and God fails to send the locusts down on that state, ${ }^{40}$ other states will follow along. This process might take years, it might take decades, but it will take place.

A skeptic can reasonably object that this is the sort of progressive, whiggish approach to history that has repeatedly been undone by the unpredictability of human events. Depressions, wars, and technological developments-to identify only the most obvious monkey-wrenches-can derail this train of legal innovation. I agree and argue only that external shocks can accelerate, as well as derail, the progression. Moreover, the critical long-term social trends work in favor of expanding gay rights. Consider what it is that distinguishes the most pro-gay countries and states in Tables 1 and 2 from the most anti-gay countries and states. An obvious variable is relative urbanization. In general, the countries and states with large rural and small-town populations are less open to gay equality than those whose populations are concentrated in large cities and their suburbs. Urbanization correlates positively with gay equality for a variety of reasons: gender-benders and sexual minorities have greater freedom in big cities to form subcultures, a phenomenon which in turn draws such people away from rural areas; urban life discourages large families and offers women more opportunities outside the home, which undermines traditional gender roles (woman gives birth to and cares for children, man earns money); and as procreation declines and social opportunities multiply in urban settings, sex for pleasure becomes relatively more acceptable. In the United States, the most pro-gay states are those of the urbanized Northeast corridor, those ringing Lake Michigan, and the West Coast states; the least pro-gay

40. Indeed, it is much more likely that the "first move" on same-sex marriage will reap economic benefits, rather than the Wrath of God. See Jennifer Gerarda Brown, Competitive Federalism and the Legislative Incentives to Recognize Same-Sex Marriages, 68 S. CAL. L. REV. 745 (1995). 
states tend to be the more rural ones of the South, Great Plains, and Rocky Mountains (Table 2).

Whatever the precise fate of big cities, clustering of human beings in urban suburban, and exurban (suburban-urban) areas appears to be a robust trend in industrialized, technology-driven modern states. That social trend undercuts attitudes that form the basis for homophobia: namely, gender rigidity and sex negativity. ${ }^{41}$ Thus, even without a step-by-step approach to gay equality, popular attitudes ought to evolve in gay-friendly ways because of urbanization alone. An increasingly urbanized population will be increasingly receptive to the incremental campaign for full gay equality.

That legal recognition of same-sex marriage is probable does not mean that such recognition will be universal. Tables 1 and 2 suggest that, even if the Netherlands and Vermont were to legalize same-sex marriage, other countries and states would not, either in the short term or in the long term. States like Mississippi and Idaho, and countries like the United Kingdom and Argentina, would be unprepared to follow Vermont and the Netherlands, to the extent that those jurisdictions continue to criminalize gay people for their consensual intimacy. However long it takes to recognize same-sex marriage in the Netherlands and Vermont, it will take much longer to do so in the United Kingdom and Mississippi. Although I think same-sex marriage is an idea whose time has come, I also think that it will not come to some jurisdictions for a long time, if ever. Countries in Northern Europe and states in the Northeastern United States are most likely to lead the way, given their readiness under the step-by-step principle, but it is really unclear how many countries or states would recognize same-sex marriage even in the medium term and even if urbanizing trends continue.

There is another variable that makes the matter even less predictable. Return to Tables 1 and 2, which show that urbanization does not perfectly correlate with advances in gay rights. This variable hardly explains why the Netherlands is more gay-friendly than the United Kingdom or why Vermont is much more gay-friendly than Michigan. Utah, Virginia, and Texas are extremely anti-gay, yet are more urbanized than Vermont and are not much less urbanized than such pro-gay meccas as Oregon and Wisconsin. Internationally, the big puzzle is why the Scandinavian countries are so much more pro-gay than comparably urbanized countries like Switzerland and, most strikingly, the United Kingdom. A secondary variable is whether fundamentalist religion plays an important role in the public culture of a Western-acculturated country or state. ${ }^{42}$ In America, states where the aggressively anti-gay Southern Baptist Convention and the Church of Jesus Christ of Latter-Day Saints have the most members are, generally speaking, the most anti-gay in their

41. See ESKRIDGE, GAYLAW, supra note 4, ch. 6; KLASSEN ET AL, supra note 34, at 225-27, 240-41.

42. Cf. KLASSENET AL., supra note 34, at 227-28, 238-39 (explaining that religious devoutness, especially when fundamentalist Protestant, most accurately predicts anti-homosexual attitudes). 
policies. Internationally, countries where organized religion has become politically domesticated (Scandinavian nations and the Netherlands) are most likely to have pro-gay policies. Countries where religious involvement in politics is viewed with suspicion (France, Belgium) are likely to have intermediate policies, and countries with active involvement of religions in politics (Latin America and the United States) will have anti-gay policies.

Unlike increasing urbanization, which seems predictable in the medium term, the role of fundamentalist religion in public culture is much less predictable. To my knowledge, no one has ever successfully predicted the trajectory of religious enthusiasm. ${ }^{43}$ Indeed, that trajectory might be influenced by gay people's efforts to secure equal rights. As gay rights and openly gay people have become part of the public culture, fundamentalist religions in the United States have not only been energized in their efforts to confront that development, but have reordered their religious beliefs to make homophobia doctrinally central. Thus, it is quite possible that recognition of same-sex marriages in one or a few jurisdictions could massively reenergize religious fundamentalism and trigger a national or transnational backlash against gay rights. If that were to occur, the United States and the world could end up with a long-term division between jurisdictions recognizing same-sex unions or marriages and those not recognizing such unions or marriages. If most states did adopt same-sex union or marriage statutes, however, the U.S. Supreme Court would probably require all states to do so as a matter of constitutional equal protection-just as it did a generation ago for different-race marriage in Loving $v$. Virginia.

\section{The Sedimentary Precept}

Each step toward same-sex marriage is typically sedimentary: ${ }^{44}$ rather than displacing earlier reforms, the new reform simply adds another legal rule or institution on top of the earlier one. In this way, the same-sex marriage movement has contributed to a transformation in the options the state offers to different-sex as well as same-sex couples. Thus, when Denmark enacted its registered partnership law, it did not revoke the legal rights of cohabiting same-sex couples. In 1998, the Parliament in the Netherlands enacted a law recognizing registered partnerships, granting to such unions most of the rights, benefits, and obligations of marriage (but not the name "marriage"). Unlike Denmark's pioneering law, the Dutch law made registered partnerships available to different-sex as well as same-sex couples, and about a third of the registrants have been different-sex couples (Table 3). This

43. Indeed, so predicting is even more treacherous than predicting the weather. Zealots and officials who were confident that the cult of Jesus could be extinguished by crucifying its leader are only the most famous example of the way in which conventional judgment fails to account for religious movements. Who would have predicted in the 1960 s that the "religious right" would be an important player in national politics in the 1980s?

44. Cf. Barry Friedman \& Scott B. Smith, The Sedimentary Constitution, 147 U. PA. L. REv. 1 (1998). 
example suggests that the experimentation in social policy triggered by the samesex marriage movement can, and perhaps ought to, create new institutions available to all kinds of couples, not just same-sex couples. Consistent with the sedimentary precept, the 1999 bill to recognize same-sex marriages in the Netherlands would not displace registered partnerships, which would remain available for different-sex as well as same-sex couples even if same-sex marriage were recognized.

The same-sex marriage movement is part of a larger evolution in the way the state regulates human coupling. Today in the Netherlands, and tomorrow in many other jurisdictions, couples of all kinds will have a menu of options:

- Dating (Tort/Criminal Law). Couples can just date and be intimate friends. Such a relationship can be important for the couple, as some people do not want any further level of commitment. These relationships are regulated by law, primarily to protect each partner against actionable wrongs committed against her by the other partner. Criminal and civil tort law prohibit sexual assault, libels, theft or conversion of assets, blackmail, and the like. This is admittedly a minimalist level of regulation.

- Cohabitation (Contract Law). Almost all couples start by dating; some of those couples then decide to cohabit. This move not only signals a closer relationship, but in Western polities often entails more legal obligations. In addition to the obligation not to commit torts or crimes, the United States, Canada, and most Western European countries impose some contractual obligations on the partners as a matter of law or implied contract. Not only will the state enforce explicit promises made to induce cohabitation and a particular sharing of duties, but the state will also protect the reliance interests of partners and protect against unjust enrichment of one partner at the expense of the other. Thus, cohabiting partners may have duties of mutual maintenance and support; a partner who furthers his career while his cohabitant maintains the household may be held financially accountable in the event of a breakup.

- Cohabitation Plus (Unitive Benefits). Some countries, such as Canada and the Netherlands, not only enforce tort law and expansive contract principles to protect cohabiting partners, but also offer the partners some specific benefits. I call them "unitive" benefits, because they typically involve rules treating the partners as coupled and granting them financial and other benefits that reflect their unity, at least as to some matters. In the United States and France, cohabitation plus is accomplished through domestic partnership and civil solidarity pacts, respectively. Under the new French law, civil partners can file joint tax returns, the state makes it easier for a noncitizen partner of a French 
citizen to immigrate to France, and employers are required to make allowances for partners' vacation plans. ${ }^{45}$ American domestic partnership laws usually just allow formal registration and provision of fringe benefits to partners of state employees.

- Registered Partnership (Regulatory Benefits and Duties). After or instead of cohabiting, many couples decide to commit to a longer-term partnership. The Netherlands and the Scandinavian countries allow these couples to register as partners. Registered partners are not only governed by tort law and contract precepts, and not only have some unitive benefits granted by the state, but also have a whole range of duties as well as benefits under state law. The only benefits usually not allowed are those relating to children, such as marital preferences in adoption and presumptions that children born in the relationship are the biological children of the couple. (The Netherlands has already dropped this exception, and other countries will likely do so as well.)

- Marriage (Regulatory Benefits and Duties). The traditional way couples commit to a long-term relationship is, of course, through marriage. Under the sedimentary precept, the state will continue to support, as well as recognize, marriage, with all the rights and duties entailed in registered partnerships as well as the children-related rights noted above. It is also possible that the state will re-think its regulatory regime, and add or subtract rights and duties to meet the social needs or preferences of the twenty-first century.

Note that each regime incorporates the rules in prior regimes and adds to them. Thus, marriage includes the criminal restrictions of the dating regime, the contract precepts of cohabitation regime, the unitive benefits of cohabitation plus, and all the benefits and duties of registered partnerships-as well as rights to adoption and the symbolic tie to Western marriage traditions. This phenomenon is consistent with the principle of sedimentation.

\section{COMPARATIVE LAW AND THE THEORETICAL DEBATE}

Even if I am descriptively right that some jurisdictions will accept the principle of formal equality and legally recognize same-sex marriages as part of the foregoing menu of options, I might be prescriptively wrong that this is a beneficent, or at worst neutral, development. The comparative law experience provides important but provisional support for the proposition that formal equality is a

45. See Proposition de Loi Adoptée par L'Assemblé Nacionale en Première Lecture, relative au pacte civil de solidarite, No. 207, 9 Dec. 1998 (visited May 2000) <http://www.senat.fr/leg/taan98-207> (copy on file with the McGeorge Law Review). 
worthwhile goal for both gay people and for the polities in which they live. First, the step-by-step process has revealed that same-sex unions, and potentially marriages, are not an oxymoron. ${ }^{46}$ Lesbians, gay men, and bisexuals can pair up with people of the same sex and form productive unions. As Table 3 shows, the numbers are quite modest, but there is reason to believe that the unions are admirable ones. The evidence from Denmark, which has had a registered partnership law since 1989, is that most of the registered couples have stayed together (the divorce rate is quite low so far). While it is too early to compare the break-up rates for same-sex and different-sex couples, such a comparison would be beside the point, for the point is that such couples undermine stereotypes about unreliable or promiscuous "homosexuals." It is also significant, and may explain the low rates of registration, that couples registering under the partnership laws are coming out as couples, and not just as individuals. Thus, the laws facilitate an intriguing new phase in the history of "coming out of the closet."

Second, the legal recognition of same-sex unions that is best supported by principles of justice and equality can, and perhaps usually does, have benign or good consequences. Denmark, Sweden, and the Netherlands have given almost complete recognition to same-sex unions, without malign consequences: there are no reports, even from traditionalists in those countries, that different-sex families have been weakened or that unhealthy promiscuity or sexually transmitted diseases have become a problem. Indeed, the scanty evidence supports the opposite hypotheses thus far. Not only have same-sex couples been able to solidify their conception of family through registering as partners, but new family-forming opportunities have been offered for different-sex couples. ${ }^{48}$ The pro-family and antidiscrimination policies of these countries have contributed modestly to campaigns to prevent the spread of sexually transmitted diseases, most prominently AIDS. ${ }^{49}$

Moreover, there is no evidence that legal recognition of same-sex unions has contributed to a decline in the institution of marriage. Reports from Denmark suggest that the opposite may be the case; in the ten years since same-sex couples have been able to register, the marriage rate for different-sex couples has been stable, and their divorce rate has declined. ${ }^{50} \mathrm{I}$ am dubious that there is a causal link,

46. Recall, however, that legally recognized same-sex unions are by no means unprecedented in world history. See, e.g., supra text accompanying note 20 (recounting the historical acceptance of same-sex unions in some cultures).

47. Of course, one does not need such a law to come out in this way. The highest ranking openly gay judicial official in the world, Justice Michael Kirby of Australia's High Court, came out publicly by identifying his spouse as Jan.

48. By the end of 1998, for example, 2,372 couples had registered under the Danish law and 5,217 under the Dutch law; 1,870 of the Dutch couples were different-sex. Supra Table 3.

49. See Benny Henriksson \& Hasse Xtterberg, Sweden: The Power of the Moral( istic) Left, in AIDS IN THE INDUSTRIALIZED DEMOCRACIES: PASSIONS, POLITICS, AND POLICIES 317, 321-22 (David L. Kirp \& Ronald Bayer eds., 1992).

50. See Darren Spedale, Nordic Bliss: The Danish Experience with "Gay Marriage" (1999) (unpublished manuscript, copy on file with author). 
for the same reasons I question opponents' confidence that same-sex marriage will ruin the institution, but the correlation between the opening up of marriage to samesex couples and a (perhaps temporary) halt in the institution's erosion for differentsex couples ought to expose the element of hysteria and irresponsibility in opponents' predictions. Furthermore, no evidence exists to show that the Danish experience caused significant distress for homophobes, and it seems extremely unlikely that any distress that has been felt by homophobes approaches the suicidal distress that anti-gay policies and attitudes have created among adolescents in this country. To be sure, the low levels of distress might owe something to the small number of same-sex couples who have registered under these laws: 2,372 after nine years of the Danish law, 674 after four years of the Norweigan law, 749 after four years of the Swedish law, 45 after two years of the Icelandic law, and 5,217 after one year of the Dutch law (Table 3). This phenomenon again illustrates how the incrementalism of gay-equality makes legal reform easier over time, but at the cost of real equality for gay people.

Third, and most interestingly, the comparative experience has much to suggest about the consequences of same-sex marriage for the law's regulation of the family. To begin with, some of what the experience teaches is consistent with conservative and progressive criticisms of same-sex marriage. Most strikingly, early experience is consistent with the feminist argument that same-sex marriage will be a means by which white male couples will align themselves with mainstream society and distance themselves from working class couples, female couples, and couples of color or of different races. ${ }^{51}$ As Table 3 shows, all the countries but Iceland have seen male couples take advantage of partnership registration at much higher rates than female couples, in some years at double or triple the rates. It may be significant, however, that the ratio of male to female couples has drastically fallen over time in Denmark, from 3:1 in 1990 to 1.3:1 in 1997 and 0.8:1 in 1998 (the later statistic shows more female than male couples registered), and began at 1.3:1 in the Netherlands. There are many possible explanations for the early disparity and the recent narrowing of the gender gap, but the evidence thus far lends tentative but modest support to this progressive criticism.

The comparative experience cuts against the progressive criticism that same-sex marriage will channel gay people into a patriarchal institution. Apart from the notion that same-sex marriage contributes to the delinking of marital partnership from gendered roles (husband = breadwinner, wife = housekeeper and child-rearer), the struggle for same-sex marriage has already yielded new civil institutions within which couples can choose to formalize their relationships-the Danish and Dutch registered partnerships, the American domestic partnerships, and the French civil solidarity pacts-and an expanded menu of options described above. Such a menu could support the traditionalist argument that same-sex marriage undermines the

51. See Ettelbrick, supra note 29, at 8-12. 
institution of marriage itself. In the Netherlands, cohabitation and registered partnerships are available to different-sex as well as same-sex partners. The principle of formal equality insists that options available to same-sex couples presumptively be available to different-sex couples. Hence, different-sex couples in the Netherlands ought to and will have the same menu of choices, thereby providing them with options short of marriage and arguably drawing some couples away from that institution. Note, however, that traditionalists have helped create their own bête noire: by opposing same-sex marriage, traditionalists have forced proponents to move more incrementally than they otherwise would and, therefore, to seek institutions short of marriage. That those institutions short of marriage have become open to different-sex couples ought not be surprising, given the gay rights movement's general commitment to the principle of formal equality and the demand for such institutions by straight and bisexual people. Likewise, the tactics of some progressive critics of same-sex marriage may make their prophecies selffulfilling. By insisting that same-sex marriage will domesticate gay radicalism and marginalize unpartnered lesbians, gay men, and bisexuals, these critics are contributing to a discourse of self-marginalization rather than exploring the new opportunities opened up by the menu of options I describe.

\section{CONCLUSION}

Conservatives and progressives will continue to be frustrated by the forward march of the same-sex marriage movement, but their frustration lies in the nature of our dynamic yet pragmatic society. Urbanization and associated developments are pressing the industrialized world toward same-sex marriage or its functional equivalent, and traditionalist resistance is either futile or counterproductive. The more traditionalists holler and obstruct, the more they will press the law to create new institutions responsive to different-sex as well as same-sex desires for union. Progressive objections to using marriage as a vehicle for gay rights are equally futile in the short term, for the simple reason that marriage has long been a focal point for desire and aspiration in our culture, and apparently for reasons that remain popular. That not only makes it an attractive aspiration for many same-sex couples, but also makes it a convenient target for gay rights activism, even in countries or states where activists have to accept compromises. In the longer term, though, I think progressive critiques will grow more persuasive, and Western polities will have to think more deeply about how best to structure the options on the menu of interpersonal commitment. 


\section{Appendix I \\ Country-by-Country Survey of Laws Relating to Sexual Minorities}

\section{Belgium}

Sodomy and Age of Consent. Sodomy was discriminalized during the French occupation of what is now Belgium (1792), but for most of Belgium's independent history (after 1830) there were different ages of consent. Section 372 of Penal Code, prohibiting homosexual contact between persons over 18 and consenting partners under 18 , was repealed in 1985 , equalizing age of consent to 16 for both homosexuals and heterosexuals. See International Lesbian and Gay Association, World Legal Survey: Belgium (visited April 2000) <http://www.ilga.org> [hereinafter cited as ILGA, World Legal Survey].

Cohabiting Couples. The Belgian legislature adopted the Law of 23-11-98 which extended legal benefits to cohabiting same-sex couples. The law is expected to be implemented in the year 2000. See ILGA, World Legal Survey: Belgium.

\section{Brazil}

Sodomy and Age of Consent. Since 1823, homosexual behavior between consenting adults has been legal-unless the adults are both soldiers. The age of consent for both homosexual and heterosexual activities is 14 years. Nonetheless, police harass gay people under "public decency" and "outrageous behavior" laws. See ILGA, World Legal Survey: Brazil.

\section{Canada}

Sodomy. Criminal Code §159(1) makes it an offense to engage in an act of anal intercourse. Section 159(2)(a) exempts private, consensual anal sex between husband and wife. Section 159(2)(b) exempts private, consensual anal sex between any two persons 18 years or older.

Age of Consent. Criminal Code $\S \S 151$ (sexual interference with child) and 153(1)(a) \& (b) (sexual exploitation of young person) are written in gender neutral terms.

Anti-Discrimination Law. Canadian Human Rights Act (a federal act), RSC 1985, c. H-6, was amended in 1996 to include sexual orientation, effective June 20, 1996, Bill C-33. In Haig and Birch v. Canada, (1992), 9 OR (3d) 495, Ontario Court of Appeals had held that Charter of Rights and Freedoms required that sexual orientation be read into Canadian Human Rights Act as prohibited grounds of discrimination. Federal Government did not appeal, so Canadian Human Rights Commission began applying the Canadian Human Rights Act throughout Canada 
as though sexual orientation were listed. Accord, Vriend v. Alburta, [1998] 1 S.C.R. 493 (Sup. Ct. Can. 1998).

Same-Sex Benefits. In Attorney General v. M. and H., [1999] S.C.R. (March 18, 1999), the Supreme Court of Canada ruled that provinces having laws conferring benefits on cohabiting different-sex partners had to extend those laws to same-sex partners as well. In February 2000, the federal government introduced legislation to create nationwide parity of benefits for same-sex couples and different-sex common law couples.

Adoption. Provincial law neither prohibits, nor expressly permits, adoption by lesbians, gay men, or same-sex couples. The effect of legislation is typically to exclude same-sex couples from adopting, while permitting single gay men or lesbians to adopt. Most adoption legislation restricts step-parent adoption to opposite sex couples, and in some jurisdictions, to married couples, making it impossible for lesbians or gay men to adopt their partner's child. See DONALD G. CASSWELl, LESBIANS, GAY MEN, AND CANADIAN LAW 290 (1996).

\section{China}

No specific statement in Criminal Code about homosexual status, but: Criminal Law Art. 106 says: "All hooliganism should be subject to arrest and sentence." In practice, hooliganism has included homosexual behavior. See THE SOCIOLEGAL CONTROL OFHOMOSEXUALITY: A MULTI-NATION COMPARISON 63 (Donald J. West et al., eds., 1997) [hereinafter cited as MULTI-NATION COMPARISON].

\section{Czech Republic}

Sodomy. Consensual homosexual behavior between adults was decriminalized in 1961 (Law 140/1961).

Age of Consent. In 1990, Law175/1990 equalized the age of consent for heterosexual and homosexual partners by repealing section 244 of the Penal Code. See MUlTi-NATION COMPARISON 246.

\section{Denmark}

Sodomy and Age of Consent. Denmark's reform of its Penal Code in 1930 dropped sodomy laws but left many discriminations in place. In 1976, the same age of consent (15 years) was adopted for both homosexual and heterosexual relations. See ILGA, World Legal Survey: Denmark.

Anti-Discrimination. In 1987, sexual orientation was added to the antidiscrimination clause contained in Penal Code (Art. 266) and to the AntiDiscrimination Act of 1971. 
Registered Partnerships. Act No. 372 of 7 June, 1989 permitted partnership registration for two persons of the same sex. Partners need not live together or have sexual relations, although one must be a Danish citizen. Regulation has the same legal effect as marriage, except where otherwise provided by legislation. References to "marriage" or "spouse" in Danish law automatically include registered partnerships, except that parties in registered partnerships cannot adopt a child and cannot have joint custody (as of 2000). See FAMILY LAW IN EUROPE 58 (Carolyn Hamilton et al. eds., 1995).

\section{England}

Sodomy. The Sexual Offenses Act of 1967 decriminalized private, consensual homosexual acts between men over the age of 21 .

Age of Consent. Criminal Justice and Public Order Act of 1994 lowered age of consent for male homosexuals to 18 years (see $\S 145$ ). Note, however, that present law sets the age of consent for heterosexual and lesbian contact at 16 years.

\section{Finland}

Sodomy and Age of Consent. Sodomy was discriminalized in 1971, but it was not until June 1998 that Parliament equalized the age of consent for homosexual and heterosexual relations. See ILGA, World Legal Survey: Finland.

Anti-Discrimination. The Constitution as amended by Law 17 July 1995/969 prohibits discrimination on account of sex, age, etc., or "any other reason related to the person," which is accepted as including sexual orientation. Law 21 April $1995 / 578$ prohibits "sexual preference" discrimination in public accommodations and employment. See ILGA, World Legal Survey: Finland.

\section{France}

Sodomy and Age of Consent. The French Revolution's criminal code of 1791 dropped the crime against sodomy, and it was never reinstated. The age of consent was equalized at age 15 in 1987. See Il.GA, World Legal Survey: France.

Anti-Discrimination. In 1985, the Prohibition of Discrimination (Art. 187-1, 187-2, 416, and 416-1) of the Penal Code was expanded to include discrimination on grounds of "moral habits," which includes homosexuality. See Loi no. 85-772 du 25 juliet 1985.

Pactes Civiles. In 1998, France adopted legislation creating new pactes civiles de solidarité for same-sex couples. See Proposition de Loi Adoptée parL'Assemblé Nacionale en Première Lecture, relative au pacte civil de solidarité, No. 207, 9 Dec. 1998 (visited May 2000) <http://www.senat.fr/leg/taan98-207>. 


\section{Germany}

Sodomy and Age of Consent. Federal Republic: Criminal Law Reform Act of 1969 decriminalized homosexual sex if partners were over the age of 21 (lowered to 18 soon thereafter).

German Democratic Republic: Art. 151, passed in 1968, deleted the simple crime of homosexuality, but penalized sexual acts carried out by an adult with a juvenile under the age of 18 who is of the same sex. After a Supreme Court decision in 1989, the East German parliament deleted Art. 151 from the Penal Code, equalizing the age of consent laws.

Unification: In 1994, Germany voided Article 175 of Penal Code, which made punishable sex between males if one of them is under the age of 18 , while the opposite sex age of consent was 14. The new Article 182 of Penal Code equalized the age of consent. See MULTI-NATION COMPARISON 262.

\section{Greenland}

Greenland is a self-governing dependency of Denmark, most of whose laws apply to Greenland as well. The main exception is that Greenland did not accept the 1989 Danish Registered Partnership Law until 1994. Such partnerships became effective in Greenland in 1996. See ILGA, World Legal Survey: Greenland.

\section{Hungary}

Sodomy and Age of Consent. In 1961, Hungary descriminalized homosexual acts between consenting adults if they were both older than 20 years. In 1967, the age of consent for same-sex intimacy was lowered to 18 years-in contrast to the age of 14 years for different-sex intimacy. See Lilla Farkas, "Nice on Paper: Legislation vs. Practice in Hungary" (1999).

Cohabitation. In its decision 14/1995, on the legal equality of same-sex partnerships, the Hungarian Constitutional Court ruled that the state could refuse to recognize same-sex marriage but was required to recognize same-sex cohabiting relationships in the same way it recognized different-sex cohabiting relationships. Parliament enacted legislation to that effect in 1996.

\section{Icelandl}

Age of Consent. In July 1992, the Icelandic parliament equalized the age of consent at 14 years for both homosexual and heterosexual relations. See ILGA, World Legal Survey: Iceland. 
Anti-Discrimination. In 1996, the Icelandic parliament amended the country's penal code to prohibit antigay hate speech and discrimination in sales or service. See ILGA, World Legal Survey: Iceland.

Registered Partnerships. In 1996, the Icelandic parliament adopted the Registered Partnership Law. Similar to that adopted in Denmark, Norway, and Sweden, the Icelandic law also gives lesbian and gay couples joint custody of the children either partner brings to the family. See ILGA, World Legal Survey: Iceland.

\section{Ireland}

Sodomy. The Criminal Law (Sexual Offences) Act, 1993, repealed the complete prohibition on al sexual acts between males, and legalized private, homosexual acts so long as both parties are at least age 17 and neither is mentally impaired.

Anti-Discrimination. An Employment Equality Bill was adopted in 1999 that protects against workplace discrimination. See ILGA, World Legal Survey: Ireland.

\section{Israel}

Sodomy and Age of Consent. In 1988, the Knesset repealed $\S 351$ of the Penal Code, which made male sodomy a crime. The minimum legal age for homosexual and heterosexual relations was equalized at age 16. See ILGA, World Legal Survey: Israel.

Anti-Discrimination. In 1992, the Knesset approved a law prohibiting job discrimination on the basis of sexual preference. See ILGA, World Legal Survey: Israel.

Cohabiting Partners. In El-Al Israel v. Danilowitz (May 1994), the Supreme Court of Israel interpreted the equality provisions of Israel's Labor Code to require employers to treat same-sex cohabiting partners similar to different-sex spouses for purposes of employment.

\section{Mexico}

Sodomy. No state Penal Code considers homosexual contact in itself a criminal offense, except that Article 201 of Penal Code of Federal District (which includes Mexico City) states: anyone "who facilitates corruption of a minor under 18 years of age ... by inducing to the practice of begging, alcoholism, to the consumption of narcotic drugs, to the practice of prostitution, homosexualism ... the punishment will be an imprisonment of 5 to 10 years" (Penal Code, 1995). 


\section{Netherlands}

Sodomy and Age of Consent. Section 248 of Criminal Code set age of consent at 21 for homosexuals, while heterosexual age of consent was much lower. This distinction was repealed by the Law of April 8, 1971, Staatsblad [the official law gazette of the Netherlands] 212.

Anti-Discrimination. Since 1992, anti-discrimination provisions of Criminal Code that ban racial discrimination have been expanded to include homosexual preference. Section 429 quater prohibits workplace discrimination. See MULTINATION COMPARISON 303-05.

Registered Partnerships. The Netherlands adopted a Partner Registration Act in 1998. Different-sex as well as same-sex couples can register as partners and are entitled to all the benefits and duties of marriage, but not the right to adopt children. Also, divorce is easier for registered partners. See ILGA, World Legal Survey: Netherlands.

\section{Norway}

Sodomy and Age of Consent. Norway in 1972 repealed Penal Code $\$ 213$, which prohibited sexual acts between men. Following repeal, the age of consent has been the same for homosexual as for heterosexual relations, age 16. See ILGA, World Legal Survey: Norway.

Anti-Discrimination. Section 135(a) prohibits discrimination against gay men and lesbians. Section 349a prohibits discrimination in business or similar activities. Both laws were adopted in 1981.

Registered Partnerships. Act of Registered Partnerships of April 30, 1993, No. 40 gives homosexuals the right to registered partnerships (see para XX), which has the same legal effect as marriage, except for right to adopt children. See Marianne Roth, The Norwegian Act on Registered Partnership for Homosexual Couples, 35 J. FAM. L. 467 (1997).

\section{Pakistan}

Sodomy. Section 377 of the Penal Code of the Islamic Republic of Pakistan prohibits "carnal intercourse against the order of nature with any man." Such acts carries with it a punishment of up to 100 lashes and from two years to life imprisonment. See MULTI-NATION COMPARISON 120. 
Russia

Sodomy. Art. 121.1 of the Russian Federation Criminal Code was repealed in 1993 as part of wide-ranging reform law. This article had made muzhelozhstvo (sex between men) punishable by imprisonment for up to 5 years. Article 121.2, in cases of sex between men involving threat or physical force, remains in effect. See MULTI-NATION COMPARISON 229-30.

\section{Scotland and Northern Ireland}

Sodomy. The English Sexual Offences Act of 1967 did not apply to Scotland, and male homosexual conduct, which remained illegal until the Criminal Justice (Scotland) Act of 1980. Following a judgment by the European Court of Human Rights (Dudgeon v. UK, 4 EHRR 149 (1981)), the provisions were extended to Northern Ireland in 1982.

Age of Consent. The Criminal Justice and Public Order Act of 1994 lowered the age of consent for private homosexual acts from the age of 21 (in section 80 of the Criminal Justice (Scotland) Act 1980 and in Article 3 of the Homosexual Offences (Northern Ireland) Order 1982) to the age of 18.

\section{South Africa}

Sodomy. The Constitutional Court of South Africa invalidated the nation's sodomy, gross indecency, and other homosexual offense laws under the 1996 and 1997 Constitutions. See National Coalition for Gay and Lesbian Equality $v$. Minister of Justice (Judgment of Oct. 9, 1998).

Anti-Discrimination. Section 9(3) the South African Constitution of 1997 prohibits the state from discrimination against anyone on the basis of sexual orientation; $\S 9(4)$ extends the anti-discrimination duty to private actors as well.

Partnership Benefits. The Constitutional Court of South Africa required the government to grant the same benefits to same-sex partners that its immigration laws extends to different-sex "spouses." See National Coalition for Gay and Lesbian Equality v. Minister of Home Affairs (Judgment of Dec. 2, 1999).

Spain

Sodomy and Age of Consent. Sodomy has not been a crime in Spain since 1822 (although "habitual homosexual acts" were criminal in 1928-32). Spain's new Criminal Code, adopted November 24, 1995, eliminated distinctions in age of consent, which is 12 years for homosexual as well as heterosexual relations. See ILGA, World Legal Survey: Spain. 
Anti-Discrimination. Article 14 of the 1978 Constitution prohibits discrimination on the basis of sex, age, religion, creed, political ideology, or "whatever other social or personal circumstance." Courts have usually fit sexual orientation under this residual category. The Law of 16-11-1995 bans sexual orientation discrimination in housing, employment, public services, and professional activities. See ILGA, World Legal Survey: Spain.

Partnership. The government has proposed a partnership law, but it has been stalled since 1997. Partnership laws were adopted at the regional level in Catalonia on 30 June 1998 and Aragon on 12 March 1999. See ILGA, World Legal Survey: Spain.

\section{Sweden}

Sodomy and Age of Consent. Same-sex intimacy was discriminalized in 1944, and the age of consent was equalized at age 15 in 1978. See ILGA, World Legal Survey: Sweden.

Anti-Discrimination. In 1987, the Parliament amended Ch. 16, par. 9 of the Penal Code to make sexual orientation a ground for unlawful discrimination in employment and provision of service to the public. An omnibus workplace antidiscrimination law went into force on 1 May 1999. See ILGA, World Legal Survey: Sweden.

Cohabitation. The Unisexual Cohabitees Act (Lag 1987:813) prescribes that the Cohabitees (Joint Homes) Act is applicable to homosexual cohabitees. This Cohabitees Act states that on the dissolution of the cohabitation, an equal division of the value of the home and household goods which have been acquired for common use shall take place. On death of a party, surviving party has right to equal division of common household goods and joint dwelling to retain as much of the property as equals twice the base sum applicable under the National Insurance Act at date of death. See ILGA, World Legal Survey: Sweden.

Registered Partnerships. Lag 1994: 1117, Om Registrerat Partnerskap, adopted June 1, 1994, effective January 1, 1995, provides a registration procedure whereby same-sex partners can obtain all the obligations and benefits of marriage, except that same-sex couples cannot (1) adopt children, (2) have access to state-provided artificial insemination, or (3) have the benefit of certain state-provided benefits. See ILGA, World Legal Survey: Sweden. 


\section{Appendix II \\ States that Include Sexual Orientation in their Penalty- Enhancement Statutes}

Vermont: VT. STAT. ANN. tit. 13, § 1455 (1993)

California: CAL. Penal Code $\S 422.75$ (West 1997)

District of Columbia: D.C. CODE ANN. § 22-4003 (Supp. 1994)

New Jersey: N.J. STAT. ANN. § 2C:12-1(e) (West Supp. 1994)

Massachusetts: MASS. ANN. LAWS ch. 265, $§ 39$ (West 1999)

Illinois: 720 ILL. COMP. STAT. 5/12-7.1 (West Supp. 1996)

Minnesota: MINN. STAT. ANN. $\$ 609.2231$ (West Supp. 1996)

Wisconsin: WIS. STAT. $§ 939.645$ (1998)

Connecticut: CONN. GEN. STAT. ANN. § 53(a)-181(b) (West Supp. 1994)

New Hampshire: N.H. REV. STAT. ANN. § 651:6(g) (1997)

Nevada: NEV. REV. STAT. § 207.185 (Supp. 1995)

Rhode Island: R.I. GEN. LAWS § 11-5-13 (1995)

Oregon: OR. REV. STAT. § 166.155 (1995)

Washington: WASH. REV. CODE ANN. § 9A.36.080 (West Supp. 1994)

Louisiana: LA. CoDE tit. 14, § 107.2 (West Supp. 2000)

Delaware: DEL. CoDE ANN. tit. 11, § 1304 (1994)

Iowa: IOWA CODE ANN. § 729A.2 (West 1992)

Kentucky: KY. REV. STAT. ANN. § 532.031 (Michie 1990 \& Supp. 1998)

Maine: ME. REV. StAT. ANN. tit. 17-A, $§ 1151$ (West 1997) 
2000/The Same-Sex Marriage Debate

Nebraska: NEB. REV. STAT. § 28-111 (1997)

Florida: FLA. STAT. ANN. § 775.085 (West 1992)

Arizona: ARIZ. REv. STAT. § 41-1822 (West 1999) (collecting hate crime data)

\section{Appendix III \\ States Recognizing Domestic Partners}

Hawaii: HAW. REV. STAT. § 572C1 (Reciprocal Beneficiaries Law)

California: CAL. FAM. CODE $\S 297$ (West Supp. 2000)

District of Columbia: D.C. CODE ANN. § 36-1402 (1981)

Vermont: Vermont Labor Relations Board decision, Grievance of B.M., S.S., C.M., and J.R., Docket No. 92-32, extends medical and dental benefits to domestic partners of state employees. 